\title{
On the Semantic of Ageing from Successful Ageing to Dynamic and Developmental Model of Ageing
}

\author{
Donatella Rita Petretto ${ }^{1 *}$, Lorenzo Pili ${ }^{2}$, Luca Gaviano ${ }^{1}$ and Roberto Pili ${ }^{2}$ \\ ${ }^{1}$ Department of Education, Psychology and Philosophy, University of Cagliari, Italy \\ ${ }^{2}$ Communità Mondiale della Longevità, Selargius, Italy
}

Submission: April 14, 2017; Published: April 19, 2017

*Corresponding author: Donatella Rita Petretto, Department of Education, Psychology and Philosophy, University of Cagliari, Via Is Mirrionis 109127 Cagliari, Italy

Abstract

During the second part of Twentieth Century worldwide there have been an important process of conceptualization on active ageing and healthy ageing, related to the progressive ageing of population in most of the countries, the so called "Demographic revolution" or "demographic transition" [1-9]. We can divide the conceptualization in different groups: American conceptual models, European conceptual models and other conceptual models related to different points of view on ageing [10-13]. The conceptualization of ageing is strictly related to the anthropological framework at the bottom of it and to the interest to all the phases of the life, but it is also strictly related to semantical choices at the bottom of the conceptual models [14-16].

In the semantic of ageing we found different words, like active ageing, healthy ageing, and successful ageing and so on. There are different variables that make the difference: a focus on subject and subjectivity, the focus on well-being and quality of life as central outcomes, and the sociocultural influences that make some variables more important than others and define the role of oldest people in the society. The aim of paper is to discuss different variables related to different semantical choices and to propose some critical hints of analysis in this field.

Keywords: Active ageing; Longevity; Positive ageing; Healthy ageing; Well-being; Quality of life; Participation; Demographic transition; Oldest olds; World Health Organization

\section{Introduction}

During the second part of Twentieth Century worldwide there have been an important process of conceptualization on active ageing and healthy ageing, related to the progressive ageing of population in most of the countries, the so called "demographic revolution" or "demographic transition"[1-9,17-21]. We can divide the conceptualization in about 3 groups: American conceptual models, European conceptual models and other models related to other points of view. The conceptualization of ageing is strictly related to an anthropological framework, but it is all strictly related to semantical choices at the bottom of the conceptual models [9,14-16].

In the semantic of ageing we found different words, like active ageing, healthy ageing, and successful ageing and so on. There are different variables that make the difference: a focus on subject and subjectivity [22,23], the focus on wellbeing and quality of life as central outcomes, and the sociocultural influences that make some variables more important than others and define the role of oldest people in the society.

Ageing is a process where something change in different aspects and domains of life and there can be a reduction of functional abilities. The speed and the quantity of this trend of reduction of functional abilities is strictly related to different variables, genetics or constitutional ones on one side and behavioral and environmental ones on the other side. There is a relative agree between scholars about the role of genetic or constitutional factors, that is limited to about $25-30 \%$ percent of change, and the role of other variables, that is about $75 \%$. These other variables that have a central role, can be modified and controlled, differently from genetic or constitutional factors. These other variables are related to behavior, lifestyles and in particular eating attitudes and behaviors, physical activities, cognitive functioning and psychosocial variables as the role in society and in family and the respect of autonomy, independency and the possibility to continue to control and decide for ourselves life.

Since 2002, World health organization (WHO) has produced different documents about active ageing [24-26]. The WHO highlights the importance of promoting active ageing, not as a secondary outcomes but as a central outcomes of any intervention in this field and of any partner countries. And this is an agreed mission, necessary to control and run 
demographic transition worldwide. According to the World Health Organization, the meaning of healthy and active ageing is not being without disorders or without disease but it refers to wellbeing from a biopsychosocial point of view, so it refers to wellbeing and quality of life. This topics are strictly subjective and individually- and sociocultural-defined. WHO define active ageing as a process of optimization of opportunity related to health, participation and security, so these are the keywords related to active ageing. And it is important to note that there are not only individual responsibility but also social responsibility in this field and the aim is to promote and increase quality of life of ageing people. WHO describes six groups of mediator variables: the availability of sociosanitary and sanitary services (related to the promotion of health and to the prevention of disorders and disease), behavioral variables (related to physical activity, diet, use and abuse of drugs, tobacco, and alcoholics), environmental factors (like the availability of accessible homes, building and cities in general, mainly to prevent the falls of old people, that is one of the much important causes of disability and death in oldest population), social factors (the role of family and micro -macro social environment), economic factors (that refers to work and other productive activities, social security and income and economic independency) [24-26].

From the Conceptualization of the WHO, the main features and the key elements that make a good quality of life, and then an active ageing, is the recognition of the centrality of the person who is ageing and the possibility to maintain, along all the phases of life, autonomy (that means maintain control and decision making in the different domains of our self life), independency (the ability to choose and do, also with help, activities of daily living) and a good quality of life [24-26].

The most world-wide known conceptual model is the one of Rowe and Kahn, named "Successful Ageing model" and that is an example of American point of view on ageing $[32,31,30,12,13]$. The term "successful ageing" is one reason of some misunderstanding about this model, but from our studies the very important aspect of this model is the reference to three kinds of ageing: "successful ageing", where there is an high level of participation in society, high level of physical and cognitive functioning and the low probability of disease, disorders and disability. "Usual ageing" refers to people that have an high risks to develop disease, disorders and disability. "Pathological ageing", the so called fragility in ageing people, refers a situation where people has a lots of different disorders, diseases or disabilities $[1-3,6,7]$.

The "usual ageing" is the real keyword of the model because it refers to people who do not have pathologies but can develop one or more, it depends mainly on lifestyles, eating behaviors and other aspects related to use and abuse of drugs, tobaccos, and alcoholics, aspects that are related to the so called "not communicable disease". So the main focus of the Rowe and Kahn model is the overcoming of the previous dual vision about pathological and not pathological ageing, a particular attention to usual ageing and the possibility to reduce the risks for people with usual ageing to develop pathologies $[1-3,6,7]$.

Other studies has discussed other semantic aspects of ageing, like the reference to "positive ageing", like in the Spanish approach promoted by Rocio Fernandes Ballesteros [10-13], and other authors from an oriental scholarship had described "harmonious ageing" [27], that has the aims to include all kinds of ageing and not to exclude anyone.

Perhaps each model and each semantic approach has disadvantages and advantages, for example also the word "active" (related to ageing) can produce misunderstanding because it can be related to some kind of "acceleration of ageing", mainly by negative factors (from and individual and social level, from environmental causes and from social causes), mainly in countries where negative environmental causes can have a negative effect on health [28]. In this framework, it could be more correct to substitute "ageing" with "longevity", a less negative word and refers to "active longevity" [28]. But it is not a simple field of discussion and of analysis and it is an open field with huge consequences at different levels [9,29-31]. So we think that it is very useful to study the role of sociocultural variables and study differences in different countries and community. How can we study the role of these variables? How can we werespect subjectivity in this field? How we can respect people and their centrality in his own-life? And then, how can we develop interventions aiming to promote well-being and good quality of life in different phases of life?

We believe that to study of "natural experiment" (like those related to communities with an high level of longevity people) could be a way to approach to these phenomenon in an "ecological manner" and "inclusive manner". To study and to learn from longevity people could help us to better know this phenomenon and to define predictors and mediators in this field. It is crucial be aware that each generalization could be dangerous, and so it is necessary to be careful in each kind of generalization from one environment to another, from one country to another, from one kind of society to another, from one socioeconomic framework to another, and, specifically, from one person to another, and so on.

In our study on longevity, mainly based on longevity community in Sardinia, an Italian island known as the first "Blue Zone" described some years ago due to an high level of oldest olds, we found interesting data about the role of sociocultural variables. Studying the ageing of people living in little cities, with a population of less then 1.000 people or between 1.000 and 3.000, in an agricultural based economy, we found data about the reference to a new model of ageing, the so called "Dynamic and developmental model of ageing" [9,14-16, 32,33]. The main features of this approach are: the role of psychological variables (like meaning of life, spirituality, coping strategies in 
front of negative life events, ability to forget negative events and to overcome negative situations, for example an old lady we interviewed in our studies said "we have the ability to get up every times we fall"), the capacity to maintain control over different domains of life, autonomy in daily life activities, the role of lifestyles (longevity people continue to make an ecological physical activity daily, like gardening, doing housekeeping and housework's, walking and doing other physical activities), the role of sardomediterranean diet (a specific kind of Mediterranean diet with high level of fruits, vegetables, milks and other products and the centrality of bread and related products and little quantity of wine), not solution of continuity in role and job, not retirement, there is no stop of the role in the society (a sheeper continues to be a sheeper also at 90 o 100 years old and a farmer continues to be a farmer also at 90 or 100 years old), not solution of continuity in the possibility to decide for our self life, the role of family and social network (relatives, and friends), the possibility to maintain independency and autonomy $[9,14-$ $16,32,33]$

\section{Conclusion}

In summary, the study of ageing and the conceptualization of ageing has been (and it is now) the focus of a great number of researches. Discussing the different semantical choices in this fields and the role of different sociocultural and economical variables related to different experiences could help scholars to create intervention aiming to maintain people who is ageing in the center of their life, to increase their participation, to respect their choices and to assure the possibility to maintain, along all the phases of life, autonomy (that means maintain control and decision making in the different domains of our self life), independency (the ability to choose and do, also with help, activities of daily living) and a good quality of life.

We aware that it is not a simple field of discussion, but perhaps we have more to learn from the experience of longevity people. And we have a great possibility thanks to the experience of longevity communities, a sort of a "natural experiment", but we must be careful in doing any kind of generalization, from one environment to another, from one country to another, from one kind of society to another, from one socioeconomic framework to another, and, specifically, from one person to another, and so on. From a psychological point of view and according to a biopsychosocial approach, the main aims in this field of study are to guarantee each person to age with well-being, dignity: a way to do this it to promote the more inclusive conceptualization on ageing $[9,34,35]$.

\section{Acknowledgment}

The Authors wish to thanks all the oldest olds that collaborate to the researches for the precious "lessons of life" they give them.

\section{References}

1. Rowe JW, Khan RL (1987) Human aging: usual and successful. Science 237: 143-149.
2. Rowe JW, Kahn RL (1998) Reply to Letter to Editor. The Gerontologist 38(2): 151.

3. Rowe JW, Kahn RL (1997) Successful aging. Gerontologist 37(4): 433440.

4. Baltes PB, Baltes MM (1990) Successful Aging: perspectives from the behavioural sciences. Cambridge: Cambridge University Press India.

5. Baltes PB, Baltes PB (1990) Psychological Perspectives on successful (proactive) aging:selective optimization with compensation. In: Baltes PB, Baltes MM (eds). Successful aging: perspective from the behavioural sciences. New York: Cambridge University Press.

6. Kahn RL (2002) Guest editorial on "successful aging and well-being: self-rated compared with Rowe and Kahn. The Gerontologist 42(6): 725-726.

7. Kahn RL (2004) Successful aging: mith and reality, The 2004 Leon and Josephine Lecture. University of Michigan School of Social Work, USA.

8. Pruchno RA, Wilson-Genderson M, Rose M, Cartwright F (2010) Successful aging: early influences and contemporary characteristics. The Gerontologist 50: 821-833.

9. Petretto DR (2016) Conceptual models of active ageing, cognitive ageing and wellbeing: from a psychological point of view - Modelli di invecchiamento attivo, invecchiamento cognitivo, benessere: in un'ottica psicologica, Seminario Internazionale di Studio "Confronto dieta sardo-mediterranea e dieta bielorussa in ordine alla promozione della salute e dell'invecchiamento attivo e sano, Ministry of Education of the Republic of Belarus, Accademia della Scienze di Minsk, Osservatorio Internazionale sulla longevità e sulle Blue Zone, Minsk -Republic of Belarus, Accademia della Scienze, Minsk.

10. Fernandez-Ballesteros Garcia R, Zamarron Cassinello, Lopez Bravo, Angeles Molinas Martinez M, Diez Nicolas J, et al. (2011) Successful ageing: criteria and predictors. Psychology in Spain 15(1): 94-101.

11. Fernandez-Ballesteros R, Schettini R, Sanatacreu M, Angeles Molina M (2012) Lay concept of aging well according to age: a reanalysis. JAGS 60(11): 2172-2173.

12. Fernandez-Ballesteros R (2011) Positive ageing: objective, subjective and combined outcomes. Electronic Journal of Applied Psychology $7(1): 22-30$.

13. Fernandez-Ballesteros R, Schettini R, Sanatacreu M, Angeles Molina M (2012) Lay concept of aging well according to age: a reanalysis. JAGS 60(11): 2172-2173.

14. Petretto DR, Pili R, Gaviano L (2016) L'invecchiamento sano ed attivo, attività di vita quotidiana, demenza: il progetto A.Te.ne (ageing and teulada's neurocognition), IX Convegno della Società Italiana di Psicologia dell'invecchiamento 20-22.

15. Petretto DR, Pili R, Gaviano L, Matos Lòpez C, Zuddas C (2016) Active ageing and success: a brief history of conceptual models, Envejecimiento activo y de éxito o saludable: una breve historia de modelos conceptuales. Revista Esp Geriatr Gerontol jul-aug 51(4): 229-241.

16. Petretto DR, Pili R, (2016) Le vie dell'invecchiamento attivo e di successo: modelli concettuali, International Congress on Active Ageing and Longevity, Giornate di Studio sull'invecchiamento Attivo e di Successo in un ottica biopsicosociale Cagliari 15-16.

17. Riley MW, Riley JW (1994) Structural lag: Past and future. In: Riley MW, Kahn RL, Foner A (Eds.). Age and structural lag 15-36.

18. Riley MW (1998) Letter to the editor. The Gerontologist 38: 151.

19. Depp CA, Jeste DV (2006) Definitions and predictors of successful ageing: a comprehensive review of larger quantitative studies. American Journal of Geriatric Psychiatry14: 6-20. 
20. Ouwehand C, De Ridder DTD, Bensing JM (2007) A review of successful aging models: proposing proactive coping as an important additional strategy. Clinical Psychology Review 27(8): 873-884.

21. Dillaway HD, Byrnes M (2009) Reconsidering successful aging: a call for renewed and expanded academic critiques and conceptualizations. Journal of Applied Gerontology 28: 702-722.

22. Cosco TD, Prina AM, Perales J, Stephan BCM, Brayne C (2013) Lay perspectives of successful ageing: a systematic review and metaethnography. BMJ, Open.

23. Cosco TD, Prina AM, Perales J, Stephan BCM, Brayne C (2014) Whose "Successful ageing"? Lay and research-driven conceptualisations of ageing weel. European Journal of Psychiatry 28(2): 124-130.

24. World Health Organization (2012) Global Health and aging. Geneva, Switzerland.

25. World Health Organization (2002) Health and Ageing: a discussion paper. Geneva, Switzerland.

26. Paul C, Ribeiro O, Teixeira l (2012) Active ageing: an empirical approach to the WHO model. Current Gerontology and Geriatrics Research pp: 10 .

27. Liang J, Luo B (2012) Toward a discourse shift in social gerontology: from successful aging to harmonious aging. Journal of Aging Studies 26: $327-334$.

28. Sidorenko A, Zaidi A (2013) Active ageing in CIS Countries: semantics, challenges and responses. Current Gerontology and Geriatrics Research.

29. Katz S, Calasanti T (2015) Critical perspectives on successful aging: does it "appeal more than it illuminates"? The Gerontologist 55: 26-33.
30. Martin P, Kelly N, Kahana B, Kahana E, Willcox BJ, et al. (2015) Defining successful aging: a tangible or elusive concept? The Gerontologist 55: 14-25.

31. Martinson M, Berridge C (2015) Successful aging and its discontents: a systematic review of the social gerontology literature. The Gerontologist 55: 58-69.

32. Pili L, Gaviano L, Invecchiamento (2016) stili vita e Dieta Sardo Mediterranea nel progetto A.Te.Ne.: le esperienze delle comunità di longevi, Seminario Internazionale di Studio "Confronto dieta sardomediterranea e dieta bielorussa in ordine alla promozione della salute e dell'invecchiamento attivo e sano, Ministry of Education of the Republic of Belarus, Accademia della Scienze di Minsk, Osservatorio Internazionale sulla longevità e sulle Blue Zone, Minsk -Republic of Belarus, Accademia della Scienze, Minsk.

33. Pili R (2016) Sardinia-Mediterranea Diet: well being and health in oldest old communities in Sardinia - Dieta Sardo Mediterranea: benessere e salute nelle comunità longeve della Sardegna, Seminario Internazionale di Studio "Confronto dieta sardo-mediterranea e dieta bielorussa in ordine alla promozione della salute e dell'invecchiamento attivo e sano, Ministry of Education of the Republic of Belarus, Accademia della Scienze di Minsk, Osservatorio Internazionale sulla longevità e sulle Blue Zone, Minsk -Republic of Belarus, Accademia della Scienze, Minsk.

34. Harmell AL, Jeste D, Deep C (2014) Strategies for successful aging: a research update. Current Psychiatry Report 16(10): 476-482.

35. Peel NM, Mc Clure RJ, Bartlett HP (2005) Behavioural determinants of health ageing. American Journal of Preventive Medicine 28(3): 298304 .

Your next submission with Juniper Publishers
will reach you the below assets
- Quality Editorial service
- Swift Peer Review
- Reprints availability
- E-prints Service
- Manuscript Podcast for convenient understanding
- Global attainment for your research
- Manuscript accessibility in different formats
( Pdf, E-pub, Full Text, Audio)
- Unceasing customer service
Track the below URL for one-step submission
https://juniperpublishers.com/online-submission.php

